\title{
Portrayal of Masculinity in Chinua Achebe's Things Fall Apart
}

\author{
Md. Hasinur Siddique \\ Assistant Teacher of English \\ Japan International Dream School \\ M.A., Jatiya Kabi Kazi Nazrul Islam University \\ Tangail, Bangladesh \\ hasinursiddique@gmail.com
}

\begin{abstract}
The paper investigates the construction and representation of masculinity in Chinua Achebe's Things Fall Apart. The study digs underneath the structure and tradition of Igbo culture which celebrates the customs centered on male dominance. The protagonist, Okonkwo turns to be the major focus of study who tries to maintain all the traits of masculinity with strict application. His extreme 'macho man' life rejects any practice which might associate him with his father. The text offers the motives behind Okonkwo's sheer concern regarding preservation of male dominance. Achebe's narrative of Okonkwo's character associating description of physical power, wealth, authority and violence portrays the masculinity in Things Fall Apart. The description of wrestling, battles, yam feasts or Clan meeting upholds the supremacy of males sending all other ideals to the periphery.
\end{abstract}

Keywords: Masculinity, Igbo Society, Construction, Manliness, Tradition. 
DOI: https://doi.org/10.24113/ijellh.v8i1.10378

Chinua Achebe's Things Fall Apartportrays Igbo society which worships idea of heroism and masculinity. As the consequence, the protagonist Okonkwo is spotted to be directed by the fear of failure and pressure of establishment throughout his life. To get rid of weakness, he sheds any kind of sensivity which might lure him to surrender to soft feeling or affection. As showing any sign of emotion is considered to be feminine, display of sheer strength is the true construction of masculinity. If a male digress from the stereotyped masculine features, he will be labelled as effeminate like Okonkwo's father Unoka. Gloverand Kaplan point out, 'the differences between men and women had to besharply emphasized and feminine traits had to be kept firmly in their proper place in men,they were a sign of weakness' (60-61).

The paper studies construction and representation of masculinity in Igbo society. Okonkwo is convinced by the concept of masculinity which is strong, dominant, competitive, egoistic and violent full of 'macho personality'. Power and authority are associated with masculinity in the novel. Okonkwo's character is the manifestation of this concept where he is on the run for achievements, recognition and control. The wrestling match against Amalinze the Cat has brought all the recognition which he craves for as,"Okonkwo's fame had grown like a bush-fire in the harmattan" (3). Celebration of male domination is evident in many occasions in Things Fall Apart. Raymond Williams finds that ruling culture yearn for "an active and continuous selection and reselection" and "a projected reality, with which we have to come to terms on its terms, even though those terms are always and must be the valuations, the selections and omissions" of "men" (16).

Display of male domination is constructed and displayed around Okonkwo in Things Fall Apart which serves as his best defense against any critical situation. To mask his insecurity and fear to be recognized as effeminate he is always on his toe to execute the conventional masculinity. It is his shield in progress and maintenance of clan life where he is 
DOI: https://doi.org/10.24113/ijellh.v8i1.10378

always conscious of preserving the prestige which he has achieved. The barren life of his father haunts him restricting him from being gentle and idle. He builds his personality judging against the traits of his father's life and always maintains the check sheet to be a contrast of his effeminate father. Okonkwo's life "depends entirely on its creator [himself] for its configuration" (Olney, 4).Umuofia's culture and Okonkwo's dominance push all the female characters and womanhood to the periphery. The clan's selected conventions hinder other aspects from flourishing and excludes from the whole scenario.

In portrayal of macho personality, Okonkwo's strong physical appearance comes first in sight in the novel. Achebe has drawn image of a man with full of appreciation for his muscle power and ability which is associated with his manliness in the clan. "He was tall and huge, and his bushy eyebrows and wide nose gave him a very severe look. He breathed heavily, and it was said that, when he slept, his wives and children in their houses could hear him breathe" (4).

The minute detail of big body, eyebrows and big nose are the standout features of Okonkwo's physic. Because of special attraction of wrestling in Igbo culture, he is celebrated with deep respect and recognition all of which come because of his bodily features. Achebe draws comparison with women to illustrate the significance of such feature which vividly portrays importance of bodily strength in masculinity of Igbo culture. The text describes, "He was a very strong man and rarely felt fatigue. But his wives and young children were not as strong, and so they suffered. (P.15)

Bravery is always celebrated as one of the integral parts in the projection of manhood. While describing Okonkwo's character, his intrepid actions are glorified throughout the novel. He is the first person in Umofia who brings a human head from war. In tribal fight he likes to lead from the front and wants everyone to aggressive in winning. Against white people, he stands like the one man army to initiate assault. Though whole clan stays quiet, he 
DOI: https://doi.org/10.24113/ijellh.v8i1.10378

takes it as his sole responsibility to resist the aggression of the white men. He blames the Abame community for not attacking and resisting the white man-

I have also heard that Abame people were weak and foolish. Why did they not fight back? Had they no guns and machetes? We would be cowards to compare ourselves with the men of Abeme. Their fathers had never dared to stand before our ancestors. We must fight these men and drive them from the land. (182)

Umofia allows violence to be a part of phallocentric world where beating anyone is the expression of manly power. Okonkwo performs domestic violence several times in the novel without receiving much of criticism. He beats his wives and son to channel his masculine anger which is excused as the allowed practice of clan. He keeps his son Nwoye on charge to check him from being effeminate. He feels his son will follow the path of his grandfather. Irelefinds, “Okonkwo's adoption of the manly ideal is excessive and even wrongheaded, as when Obierika emphatically expresses to Okonkwo himself his lack of enthusiasm for the prowess in wrestling demonstrated by his own son, Maduka" (130).Okonkwo has always believed that being able to keep the household under control is a prime feature of manliness. He thinks, "no matter how prosperous a man was, if he was unable to rule his women and his children (and especially his women) he was not really a man" (46).

The masculinity of Okonkwo is largely constructed around hiding of emotion. As the part of manhood, he believes that showing emotion is one type of weakness. He likes his daughter Ezinma but he retricts him from expressing it. When Agbala takes her to cave, he checks his emotion too. He takes the idea of man to the extreme and refuses the instinctive expression of human. The fear to be considered as less of man makes a cage from where he lives forever. Jeyifo believes that Okonkwo destroys the structure of gender in culture: 'Okonkwo both loathes the memory of his father and represses the lore of his mother; in the 
DOI: https://doi.org/10.24113/ijellh.v8i1.10378

process he distorts both the "masculine" and the "feminine", by keeping them rigidly apart and by the ferocity of his war on the "feminine"" (851). To run away from the shadow of his father, he engages in the murder of Ikemefuna. Ikemefuna is like a son to him and Okonkwoalso feels in that way. Though the wise clan person suggests him not to join in killing, he does not refrain. He fears that he will be judged as coward. He uses his own machete to cut him down though he feels depressed for that for a long time. "Okonkwo did not taste any food for two days after the death of Ikemefuna" (55). His concept of masculinity forces him to join in killing.

Possession of wealth is a major indicator in estimation of manliness in Igbo society. Without enough prosperity, a person is face ridicule from neighbors. Okonkwo's father has faced this embarrassment throughout his life. : "Unoka was, of course, a debtor, and he owed every neighbor some money, froma few cowries to quite substantial amounts." (4) Not only wealth but also number of wives, children and barns contribute in construction of masculinity in the society. As a result, males are always driven by the motives to build their material profile according to the requirement of the society. Achebe describes a person's status associating with his acquisition of wealth which is well acknowledged in the Igbo society.

With Igbo society's submission to the concept of maleness and femaleness, journey of each man seems to be pre decided. From the childhood Okonkwo sees what is celebrated around him and he clearly knows what he will have to achieve to acquire recognition from the society. The ideals limit him to a reduced version of human being who is convinced to repress himself in expressing emotion. He hides whatever is regarded as feminine. So he represses his spontaneous flow of feeling and emotion which might portray him as an effeminate person in the society. After achieving prestige in the clan, he becomes hyper sensitive in choice of emotional expression. He is dozed to maintain the format of masculinity by any means. 
DOI: https://doi.org/10.24113/ijellh.v8i1.10378

Failure in any sector in life is another fearsome event for males. The manliness image does not accept any sort of failure in life. In domestic life, he will have to hold sheer control over his wives and children. To express authority, he is allowed to beat his wives as well. In social life, he needs to manage prestigious recognition from the clansmen. Winning the prestige is not enough though. Because he will have to behave in particular way to sustain the recognition. In economic life, not possessing the ability to provide for the family is a serious failure as well.

Okonkwo is so much conditioned by masculinity that he categorizes food item in gender. Submitting to his clansmen, he accepts that the belief that yam is the king of all crops. When his mother and sister were working so hard to provide for the family, he is obsessed with type of yam they are producing. This phallocentric ideals clouds his mind as he considers coco-yams, beans and cassava to be female type of crops. As there is no men to help in the field, the women failed to produce yam, which reflects manliness among food items.

Challenge to masculinity is totally unacceptable to Okonkwo. He does not even know how to handle that without violence. At the time of New Yam Festival, his second wife passes some relax time because that is the day of feasting when everyone celebrates. But Okonkwo finds that a sign of laziness. He brings up the topic of cutting down a banana tree and makes the excuse to beat him. When his daughter, Ezinma fell sick, he refuses to listen to Ekwefi because that will be listening to a woman. He lets the situation flow without any interruption of oracle.

Okonkwo's belief in masculinity brings down his own life. When the messengers come, he takes the authority to draw first attack without consulting others. He is so blind with pride and authority that he does not find the necessity to discuss any further with the clansmen. After killing a messenger he finds that his clansmen have taken no action against 
other messengers who have escaped. All on a sudden he comes to the understanding how fruitless his actions has been. He is all alone and only waiting for the further downfall when no one will stand beside him. He cannot stand such lonely situation and hangs himself.

The patriarchal dominance in Igbo culture is manifested through the character of Okonkwo who lives his whole life running away from femininity. The atmosphere of Umofia recognizes supremacy of male dominance which dashes all the female characters to the background. Selected rituals and customs are centered on the male characters where the women stand as mere props. Okonkwo's dominance omits the possibility of the representation of any other values. Hyper-masculinity of Okonkwo leaves him in a sea of formats from where he can never find any escape. The idea of masculinity does not compromise with its standards in Igbo culture. As a result, the protagonist leads a pre-decided life from his childhood driven by the macho man concept which he picks up in his early age. Okonkwo takes the standards to extreme of his lifestyle being always conscious of its maintenance which brings downfall of his life eventually. 


\section{Works Cited}

Achebe, Chinua.Tings Fall Apart. London: Heinemann, 1986

Irele, F. A. 'The crisis of cultural memory in Chinua Achebe's Things Fall Apart', in The African Imagination: Literature in Africa and the Black Diaspora, Oxford: Oxford University Press, pp. 115-53.

Jeyifo, B. (1993) 'Okonkwo and his mother: Things Fall Apart and issues of gender in the constitution of African postcolonial discourse", Callaloo 16(4): 847-58.

Kapline, C., \& Glover, D. (2000). Genders. London: Routledge

Olney, James. Metaphors ofSelf: The Meaning of Autobiography. Princeton: Princeton UP, 1972.

Williams, Raymond. Problems in Materialism and Culture: Selected Essays. London: Verso, 1980. 